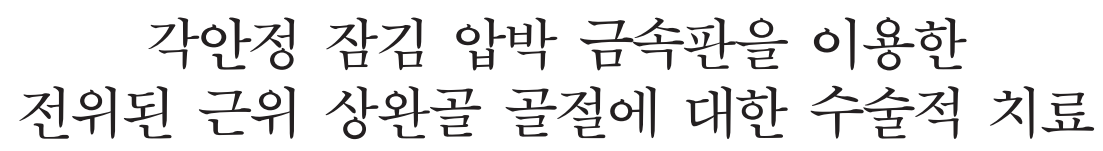

성균관대학교 삼성창원병원 정형외과학교실

김동욱 · 김종관 - 정성원 · 김현수

\title{
Operative Treatment of Displaced Proximal Humerus Fractures with the Angular Stable Locking Compression Plate
}

\author{
Dong-Wook Kim, M.D., Chong-Kwan Kim, M.D., Sung-Won Jung, M.D., Hyeon-Soo Kim, M.D. \\ Department of Orthopaedic Surgery, Samsung Changwon Hospital, Sungkyunkwan University
}

\begin{abstract}
Purpose: We examined the clinical and radiological outcomes for displaced proximal humerus fractures that were treated with a PHILOS angular stable plate.

Materials and Method: Forty four patients who underwent surgery between March 2007 and February 2010 were included in this study. All the cases were followed up for an average of 12 months. All the patients were examined and interviewed using the Visual Analog Scale (VAS) score, the Constant score and standardized Xrays to check the neck-shaft angle (NSA) and the presence of medial support.

Results: The average Visual Analog Scale score was 2.8 points and the average Constant score was 70.5 points. The average neck shaft angle was $122.5^{\circ}$ and this was statistically significant between the good result group and the poor result group. There were 36 cases of the presence of medial support and 8 cases of the absence of medial support and the difference was statistically significant. Complications such as fixation failure happened in 12 cases.

Conclusion: PHILOS angular stable plate fixation as an operative treatment for displaced proximal humerus fractures is a good and reliable treatment option.
\end{abstract}

Key Words: Humerus, Displaced proximal humerus fracture, Angular stable locking compression plate, PHILOS plate

\section{서 론}

전위가 경미한 근위 상완골 골절은 대개 보존적 치료 를 시행하나 전위된 골절은 대부분 수술적 치료를 시행 한다. 여러 저자들은 전위가 심하거나 분쇄가 있는 근
위 상완골 골절의 경우 보존적 치료보다는 수술적 치료 후 조기 재활 치료가 견관절의 통증과 운동범위를 회복 시키는 것이 중요하다고 보고하였다. ${ }^{1-3)}$ 수술적 치료 방 법으로는 다발성 $\mathrm{K}$ 강선 고정술 및 긴장대 술식, 금속 판 및 나사 고정술, 골수강내 고정술, 인공 관절 치환

\footnotetext{
※통신저자: 정 성 원

경상남도 창원시 마산회원구 합성 2 동 50 번지

성균관대학교 삼성창원병원 정형외과학교실
}

Tel: 055) 290-6030, Fax: 055) 290-6888, E-mail: can1204@hanmail.net

접수일: 2011년 4월 22일, 1차 심사완료일: 2011년 5월 17일, 2차 심사완료일: 2011년 5월 30일, 게재 확정일: 2011년 6월 1일 
술 등의 다양한 고정 방법들이 시행되고 있으며 그 결 과도 다양하게 보고되고 있다. ${ }^{4)}$

골다공증이 있거나 분쇄를 동반한 골절의 내고정술은 고정방법에 따라 수술 후 결과에 차이를 보이고 있다. 정복 소실이나 고정물 실패, 불유합이나 부정유합, 충 돌 증후군이나 상완골 골두의 골괴사와 같은 여러 합병 증이 발생할 가능성이 높은 것으로 보고되고 있다. ${ }^{5)}$ 잠 김 압박 금속판은 전통적인 기존의 $\mathrm{T}$ 형 금속판 혹은 압 박 금속판에 비해 골절편으로 가는 혈액 공급을 보존할 수 있고 초기 견고한 각 안정성 및 회전 안정성을 얻을 수 있어 조기에 관절 운동을 가능하게 하는 장점이 있 으나, 금속판 제거 시 나사가 파괴될 수 있고, 골다공 증이 심하거나 심한 분쇄를 동반한 경우에는 정복 소실 및 고정물 실패가 발생하여 이차적으로 인공 관절 치환 술이 필요할 수도 있다는 단점이 있다. ${ }^{6-8)}$ 각 안정 잠김 압박 금속판 (angular stable locking compression plate)은 골다공증이 동반된 골절에서 생리적인 부하를 이겨낼 수 있는 정도의 고정력을 가지는 것으로 보고되 고 있으며, ${ }^{4.9)}$ 근위 상완골 골절의 안정적인 고정을 위 한 골절의 해부학적, 기하학적 연구와 고정물의 형태 개선 및 새로운 수술 접근법에 대한 연구가 다양하게 진행되고 있다. ${ }^{10,11)}$ 이에 저자들은 전위된 근위 상완골 골절에 직접 혹은 간접 정복 후 PHILOS 금속판을 이 용한 내고정술을 시행하여 임상적 및 방사선학적 평가 를 통해 그 유용성을 알아보고자 하였다.

\section{연구 대상 및 방법}

\section{연구 대상}

2007년 3월부터 2010년 2월까지 본원에서 근위 상완 골 골절로 PHILOS 금속판을 이용한 고정술을 시행한 44 명의 환자를 대상으로 하였다. 남자가 18 예, 여자가 26예였으며 평균 연령은 63.5세 (24 90세)였다. 단순 방사선 사진에서 골절의 분류는 $\mathrm{Neer}^{12)}$ 분류법과 $\mathrm{AO}$ 분류법을 사용하였으며, 환자군은 Neer 분류법을 기준 으로 골편의 전위가 $10 \mathrm{~mm}$ 이상, 대결절에서는 5 $\mathrm{mm}$ 이상, $45^{\circ}$ 이상의 각형성, 내측 골간단 구조의 소
실, $2 \mathrm{~mm}$ 이상의 관절 내 골절을 대상으로 하였고, 개방성 골절, 병적 골절, 신경 혈관 손상을 동반한 경 우는 배제하였다 (Table 1). 수술 접근법은 삼각 흥간 접근법이 24예, 최소 침습 접근법이 20예로 골이식은 시행하지 않았다.

임상적인 평가는 평균 12 개월 (6 24개월)의 추시에서 Visual Analog Scale (VAS)과 Constant ${ }^{13)}$ 점수를 이 용하였으며, 우수 (86점 이상), 양호 (71 85점), 보통 (56 70점), 불량 (55점 이하)으로 나누어 평가하였다.

방사선학적 평가는 1 개월 간격의 정기적인 추시 방문 에서 촬영한 단순 방사선 검사를 통해 골유합의 유무를 관찰하고 최종 추시의 전후면 사진에서 해부학적 경부 에 수직선과 골간에 대한 평행선이 이루는 각인 경간각 (neck-shaft angle)을 측정하여 Paavolainen 등 ${ }^{14}$ 의 방법에 의해 우수 $(120 \sim 140)$, 보통 (100 120), 불량 (100 미만)의 3군으로 나누어 평가하였다 (Table 2). 또한 내측 지지대 (medial support)의 존재 유무에 따 라 2 군으로 나누어 임상적인 결과를 평가하였다. 내측 지지대의 존재는 Gardner 등 ${ }^{15.16)}$ 의 방법에 따라 근위 골편의 내측 지주가 존재하거나 해부학적으로 정복된 경우, 상완골 간부가 골두편으로 감입된 경우, 그리고 금속편의 나사가 상완골 근위 골편의 내하측 연골하 5 $\mathrm{mm}$ 이내로 삽입된 경우로 정의하였다.

최종 추시에서 골절의 정렬, 나사의 관절 내 침범 혹 은 이완, 내반 변형, 상완골두의 무혈성 괴사, 금속판 의 고정 실패 등의 합병증 유무를 관찰하였다.

Table 1. Summary of the patients characteristics

\begin{tabular}{lcc}
\hline \hline Objectives & \multicolumn{2}{c}{ Cases } \\
\hline Male: female (cases) & \multicolumn{2}{c}{$18: 26$} \\
Mean age (years) & $63.5(24 \sim 90)$ \\
Follow up period (months) & \multicolumn{2}{c}{$18(6 \sim 34)$} \\
Neer classification & Two part & 22 \\
& Three part & 14 \\
AO classification & Four part & 8 \\
& Type A (A1:A2:A3) & $15(7: 4: 4)$ \\
& Type B (B1:B2:B3) & $20(12: 5: 3)$ \\
& Type C (C1:C2:C3) & $9(1: 3: 5)$ \\
\hline
\end{tabular}

Table 2. Comparative analysis of the groups according to two subscales of neck shaft angle (NSA) \& medial support

\begin{tabular}{|c|c|c|c|c|}
\hline & Range & Cases & Mean Constant score & $p$ value \\
\hline \multirow[t]{3}{*}{ Neck shaft angle } & $120 \sim 140^{\circ}$ (Good) & 28 & 82.4 & $p=0.01$ \\
\hline & $100 \sim 120^{\circ}$ (Fair) & 12 & 74.6 & \\
\hline & $<100^{\circ}$ (Poor) & 4 & 61.2 & \\
\hline \multirow[t]{2}{*}{ Medial support } & Present & 36 & 78.8 & $p=0.02$ \\
\hline & Not present & 8 & 64.5 & \\
\hline
\end{tabular}


통계학적인 분석은 SPSS 통계 프로그램 (SPSS 10.0, Chicago, Illinois, USA)를 사용하여 paired t-test를 시행하였으며 $p$-value가 0.05 미만인 경우 통계적으로 유의한 것으로 간주하였다.

\section{수술 방법}

전신 마취 하에 방사선 투과성 침대에 약 60 도의 해 변 의자 자세에서 수술을 진행하였다. 먼저 도수 정복 술을 시행한 후 $\mathrm{C}-\mathrm{arm}$ 영상증폭기로 전후상 및 측면 액와상을 촬영하여 정복상태를 관찰하였다. 3 분 골절의 경우는 극상건에 의해 대결절이 근위부로 당겨지며 견 갑하건에 의해 상완골 골두는 내회전되고, 상완골 간부 는 대흥근에 의하여 내측으로 전위되고 상완이두근 장 두에 의하여 전방 각형성이 되므로 골편의 정복을 위해 견인과 대항 견인, 상완골 간부의 내회전, 내측 압박, 거상을 시행하였다.

삼각 흥간 접근법 (deltopectoral approach)으로 수 술을 시행한 경우 오훼돌기에서부터 약 $10 \mathrm{~cm}$ 피부 절 개를 시행하고 삼각근과 대흥근 사이로 접근하였다. 쇄 골 흥막 근막을 절개하고 이두박건 주위의 전 회선 상 완 동맥과 상완골 경부 주위의 액와 신경에 주의하면서 골절 부위를 노출하였다. 골절부의 관혈적 정복 후 PHILOS 각안정 잠김 압박 금속판 (Synthes, Stratec Medical Ltd, Switzerland)을 이용하여 나 사 고정하였다. 극상근의 회전근 개에 비 흡수성 봉합 사를 걸고 금속판 근위부의 작은 구멍에 고정하여 술 후 내반 변형을 줄일 수 있게 하였다.

최소 침습 접근법으로 시행한 경우는 삼각근 절개 접 근법 (deltoid splitting approach)으로 견봉의 전외 측 모서리에서 시작하여 원위부로 $5 \mathrm{~cm}$ 까지 연장하여 삼각근을 박리한 후 대결절을 노출하였다. 상완골 외측 면에서 약 $3 \mathrm{~cm}$ 의 원위부 절개를 추가하였으며 정복이 부족한 경우 골갈고리 (bone hook) 등을 이용하여 추 가 정복을 시도하였다. 골편의 정복 후 잠김 압박 금속 판을 대결절에서 최소 $5 \mathrm{~mm}$ 원위부, 이두간구에서 2 $\mathrm{mm}$ 후방 위치의 절개 부위를 통해 삽입하고, 액와 신

Table 3. Functional results

\begin{tabular}{ll}
\hline \hline Methods & Scores \\
\hline VAS (mean value) & $2.8(0 \sim 5)$ \\
Constant (mean value) & $70.5(35 \sim 90)$ \\
- Pain & $12.1(8 \sim 15)$ \\
- Strength & $17.8(10 \sim 25)$ \\
- Activities of daily living & $16.4(12 \sim 20)$ \\
- Range of motion & $24.2(10 \sim 35)$ \\
\hline
\end{tabular}

경에 주의하면서 근위부 $4 \sim 5$ 개 나사, 원위부 $2 \sim 3$ 개의 나사를 삽입하였다. 금속판의 고정 후에는 $\mathrm{C}-\mathrm{arm}$ 영상 증폭기를 이용하여 골절편의 안정성과 정확한 금속판과 나사의 위치를 확인하였다.

골절편의 안정성에 따라 $\mathrm{U}$ 형 석고 부목 또는 팔걸이 (arm-sling)를 이용하여 4 6주간 고정하였으며 그 기 간 동안 추운동 및 수동적 전방 거상 운동을 시행하였 다. 수술 4 6주 후 외회전 및 내회전을 포함한 능동적 보조 운동을 시행하였다. 수술 8 주 후 능동적 관절 운 동 및 일상 생활을 시작하였으며 수술 3 개월 후 일이나 운동, 근육 강화 운동을 시작하였다.

\section{결 과}

골절은 Neer 분류법에 의해 2 분 골절이 22 예, 3 분 골절이 14 예 그리고 4 분 골절이 8 예였다. $\mathrm{AO}$ 분류법 에 의해 $\mathrm{A}$ 형 골절이 15 예, $\mathrm{B}$ 형 골절이 20 예 그리고 $\mathrm{C}$ 형 골절이 9예였다.

수술 후 최종 추시의 VAS 점수는 평균 2.8점 (0 5 점)이었고, Constant 점수는 평균 70.5점 (35 90점)으 로 우수 8예, 양호 20 예, 보통 12 예, 불량 4 예였다. 방사 선학적인 결과는 경간각은 평균 122.5 도 (90 140도)로 양호 28예, 보통 12 예, 불량 4 예였으며 양호군의 Constant 점수는 평균 82.4점으로 불량군 (평균 61.2점)에 비해 통계적으로 유의한 소견을 보였다 $(p=0.01)$. 내측 지지대가 존재하는 36 예의 Constant 점수는 평균 78.8 점, 존재하지 않는 8예의 경우 평균 60 점으로 통계적으 로 유의한 소견을 보였다 ( $p=0.02)$ (Table 3$)$.

12 예 $(27.3 \%)$ 에서 합병증이 관찰되었다 (Table 4 ). 1 예 (8.3\%)에서 금속판이 상방으로 위치하여 경미한 금속판에 의한 견봉하 충돌 증상을 호소하였다. 2 예 (16.7\%)에서 관절와 상완 관절내로의 나사 천공이 발 생하였다. 이 중 1 예에서는 재수술을 시행하였고, 다른 1 예는 $2 \mathrm{~mm}$ 천공으로 판단하여 경과를 관찰하였다. 3 예에서 근위부 나사의 이완 (cut out)이 발생하였으나

Table 4. Summary of complications

\begin{tabular}{lc}
\hline \hline Complications & Cases \\
\hline Plate impingement & 1 \\
Proximal screw perforation & 2 \\
Proximal screw loosening & 3 \\
Superficial infection & 1 \\
Osteonecrosis & 2 \\
Reduction loss and fixation failure & 2 \\
Axillary nerve injury & 1 \\
\hline Total & 12 \\
\hline
\end{tabular}


골유합 진행 소견을 보여 경과 관찰하였다. 기저질환으 로 당뇨와 조기 간경화를 가지고 있는 1예 (8.3\%)에서 는 표피의 상처 감염이 발생하여 변연 절제술 및 지연 봉합을 시행하였으며. 2예 (16.7\%)에서는 상완골 골두 의 골괴사가 발생하여 인공 관절 치환술을 시행하였다. 2예 $(16.7 \%)$ 에서 정복 소실 및 고정물의 실패가 발생 하여 인공 관절 치환술을 시행하였다. 경간각이 내반된 상태로 고정된 1 예에서 수술 4 주 후 상완골 골두의 붕 괴가 발생하였다. 다른 1 예는 심한 골소실을 동반한 분 쇄 골절로 수술 10 일 후 정복 소실 및 고정물의 실패가 발생하여 모두 인공 관절 치환술을 시행하였다. 6예에 서 전방 굴곡 및 외측 외전에 장애를 보이는 액와 신경 손상이 의심되었으며, 그 중 1 예 $(8.3 \%)$ 에서는 신경 전도 검사 상 축삭 절단으로 진단되었으나 최종 추시 결과에서 통증 및 운동장애는 저절로 호전되었다.

\section{고 찰}

상완골 골절 수술의 목표는 최대한의 기능 회복을 위 한 골절의 정복 및 견고한 고정에 있다. 경간각이 내반 된 상태로 정복되어 고정된 경우나 골소실이 심하여 적 절한 정복이 이루어지지 않으면 추후 고정 실패가 올 수 있으므로, 정확한 정복 및 견고한 고정은 정복 소실 과 골절된 골편의 붕괴 예방에 필수적이다.

기존의 T형 금속판 혹은 칼날 금속판 (blade plate) 을 이용하여 골다골증이 있거나 4 분절의 심한 분쇄가 있는 근위 상완골 골절에서 고정을 시행할 경우 정복 소실과 2 차적인 금속판 고정 실패가 발생할 수 있으며 광범위한 연부 조직 박리로 인한 골편 및 상완골 골두 의 괴사가 발생할 수 있다. ${ }^{17)}$ Kristiansen 등은 $\mathrm{T}$ 형 금속판을 이용한 수술적 치료 후 만족할만한 정복과 골 절의 유합을 얻을 수 있었으나, 골다공증 환자에게서 견고한 내고정을 할 수 없어 조기 운동이 어렵고, 금속 판에 의한 충돌 증후군이 발생하고 나사의 이완에 따른 고정 소실 및 불유합 등의 합병증이 발생할 수 있다고 보고하였다.

이러한 고식적인 금속판의 단점을 보완하기 위해 최 근 사용되고 있는 잠김 압박 금속판은 부피가 작고 낮 은 강성과 높은 탄성을 가지고 있으며 초기 안정성 및 회전 안정성이 높아 견고한 고정력을 가질 수 있어 골 다공증이 있는 노령의 환자에게도 사용될 수 있다. Lill 등 ${ }^{410)}$ 은 내고정물의 생역학적 실험을 통한 비교 결과, 잠김 금속판의 경우 강성이 낮고 탄성이 높아 내고정물 과 골절편간의 저항력을 최소화하여 특히 골다공증이 심한 환자에게도 사용할 수 있다고 보고하였다.

여러 저자들에 의해 잠김 금속판을 이용한 임상적 치 료 결과들이 보고되었는데 Bjorkenheim 등 ${ }^{18}$ 은 72 명
의 근위 상완골 골절 환자에 대하여 잠김 압박 금속판 을 이용하여 고정한 결과 Constant 점수가 $50 \%$ 이상 에서 우수 이상을 보인다고 하였으나, 나이가 많아 골 다공증이 심하거나 분쇄가 심한 $\mathrm{AO}$ 분류 상 $\mathrm{C}$ 형 골절 환자에서는 불량한 임상적 결과를 보인다고 보고하였 다. Kettler 등 ${ }^{19}$ 은 근위 상완골 골절 176예를 잠김 금 속판을 이용하여 고정한 후, 추시한 결과 평균 70점의 Constant 점수를 보고하였다. 저자들의 6 개월 이상의 추시 관찰 결과에서도 평균 70 점의 Constant 점수를 보였다.

근위 상완골의 해부학적 정복에 가장 중요한 두가지 요소는 경간각의 유지와 내측 지지대의 회복이다. Agudelo 등 ${ }^{20}$ 은 잠김 금속판을 사용하여 치료한 결과 수술 후 경간각이 120 도 미만으로 내반 정복된 경우 그 렇지 않은 경우보다 더 흔하게 금속물 고정 실패가 발 생한다고 하였다. Gardner 등ㄷ.16)도 근위 상완골 골절 에 있어 내측 피질골 지지의 중요성을 강조하고 해부학 적인 정복 또는 경도의 감입 정복, 상완골 근위 골편의 하내부에 나사를 이용한 고정 등이 정복을 유지하는데 중요하다고 하였다. 저자들의 연구에서도 경간각이 100 도 이하이거나 100 도 이상이더라도 내측 지지대가 존재 하지 않은 분쇄가 심한 골절의 경우 수술 후 정복 소실 과 고정물의 실패 소견을 보여 근위 상완골 골절에서는 상지의 다른 골절보다 정확한 해부학적 정복이 중요하 다고 생각하였다.

삼각 흥간 접근법은 근위 상완골 골절의 가장 일반화 된 접근법이나, 광범위 연부조직의 절제와 삼각근의 일 부 분리를 피할 수는 없으며, 이는 상완골 골두에 혈류 공급을 하는 전 상완 회선 동맥이 손상될 가능성이 있 어 골절된 부분의 비혈관화 (devascularization)의 위 험성이 있다. 금속판을 이용한 내고정술은 높은 골 유 합률을 보고하고 있으나 합병증의 발생과 재수술의 위 험성이 있다. Thanasas 등 ${ }^{21}$ 은 금속판을 이용한 고정 술 후 Constant 점수가 평균 74.3 까지 향상되었으나, 무혈성 괴사 $(7.9 \%)$, 나사 절단 $(11.6 \%)$, 재수술 $(13.7 \%)$ 의 합병증이 발생하였다고 보고하였다. Sproul 등 22 은 514 예의 12 개의 논문에서 평균 Constant 점수는 74 점이었으나 내반 부정유합은 $49 \%$, 내 반 부정유합을 제외한 부정유합은 $33 \%$, 재수술율은 $14 \%$ 로 보고하였다. 일반적으로 내반 부정유합, 무혈성 괴사, 상완골 골두에서 관절내로의 나사 천공, 견봉하 충돌, 감염의 부작용은 각각 $16 \%, 10 \%, 8 \%, 6 \%$, $4 \%$ 라 보고되고 있다. ${ }^{23.24)}$ 근위 상완골 골절 수술 후 합 병증은 20 30\%의 비교적 높은 빈도로 발생하는 것으 로 보고되고 있다.

최근 최소 침습 접근법을 이용한 골절의 고정은 관혈 적 광범위 접근법에 의한 고정술에 비해 생물학적 치유 

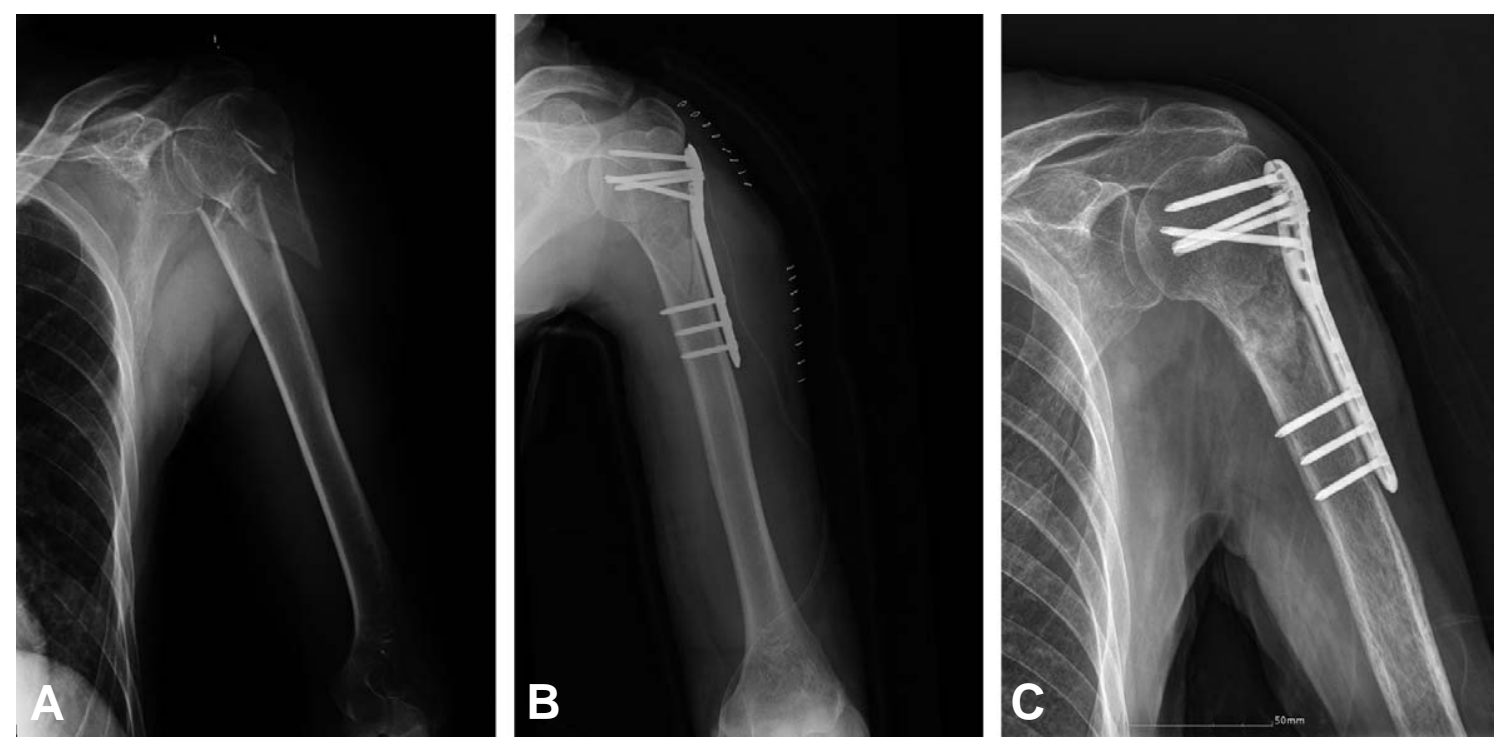

Fig. 1. 78 year old man with three part fracture and C1 fracture. (A) Preoperative radiograph. (B) Postoperative radiograph shows that NSA was $130^{\circ}$ and the medial cortex was anatomically reduced. (C) Radiograph at 6 months shows good alignment and bone union.
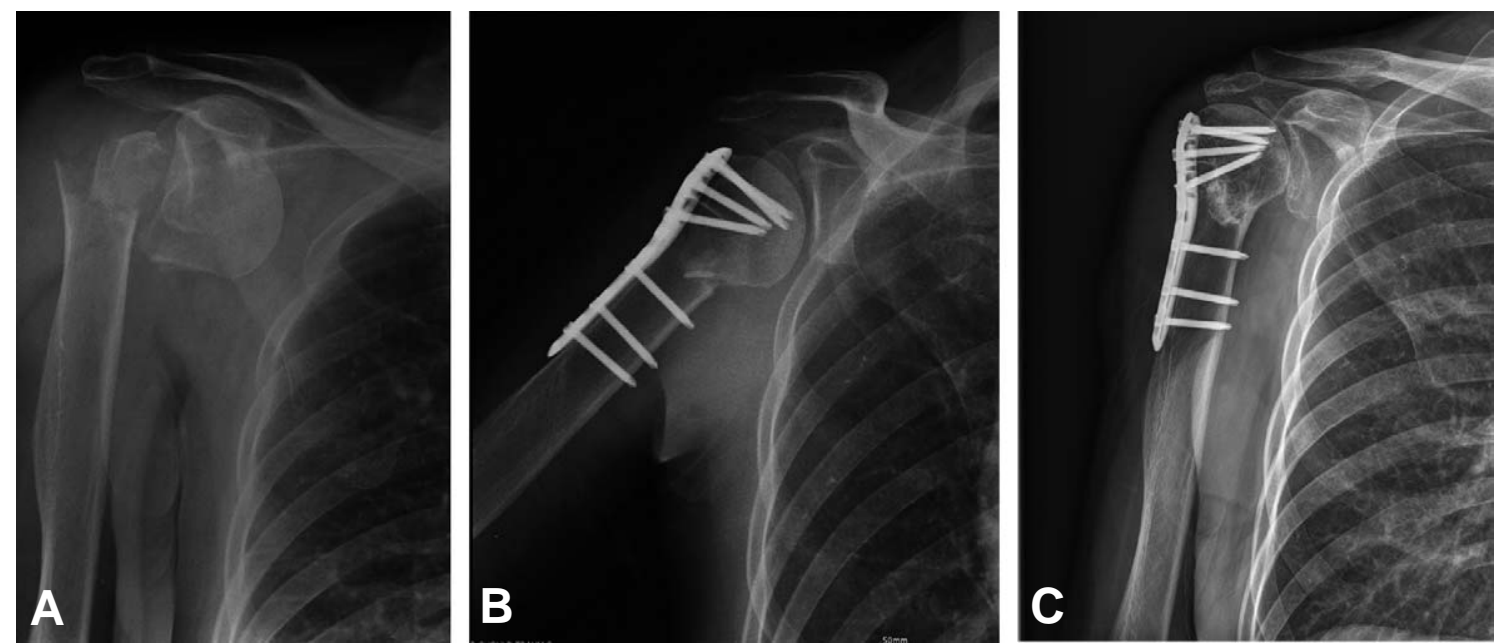

Fig. 2. 68 year old woman with fracture and dislocation of the proximal humerus and B3 fracture. (A) Preoperative radiograph. (B) Postoperative radiograph shows that NSA was $130^{\circ}$ but the medial cortex was not anatomically reduced. (C) Radiograph at 18 months shows bone union and relative varus alignment.

를 유도하는 접근법으로 보고되고 있으며, 근위부 상완 골 골절에서 최소 침습 접근법에 대한 여러 임상적 보고 들은 최소 침습 접근법의 유용성을 뒷받침하고 있다. ${ }^{6.23)}$ 최소 침습 접근법은 골다공증이 동반된 대결절 골절에 서 지지대 금속판 (buttress plate)으로 이용되고 골간 단 골간 골절 (meta-diaphyseal fracture)에서도 변 형된 방법으로 이용될 수 있으며, Rancan 등 ${ }^{25}$ 은 길이 가 긴 PHILOS 금속판을 이용한 최소 침습적 접근법을 이용한 고정이 상완골 근위부의 골간단 골간 골절의 안 전한 치료법이라 주장하였다. 반면에 Krappinger 등 ${ }^{26}$ 은 고정 방법보다는 골의 질이나 환자의 나이, 해부학
적 정복 및 내측 피질골 지지대 (medial support)의 존재 유무가 중요하며, 일차적 관절 치환술은 해부학적 정복 및 내측 피질골 지지대의 복원 가능 여부에 따라 고려되어야 한다고 주장하였다. 양호한 임상적 결과에 도 불구하고 보존적 치료나 관혈적 정복술에 비한 우월 성은 논란의 여지가 남아있다. $\left.{ }^{4}\right)$

4 분 골절에서 최소 침습 접근법을 이용한 고정술로 견고한 고정이 가능한지에 대해서는 의문의 여지가 있 으며, ${ }^{24.27)}$ 외반 감입 골절 (valgus impacted fracture)에서는 견고한 고정이 가능하나, 내반형 골절 (varus extended fracture)에서는 사용되기 힘들다. 

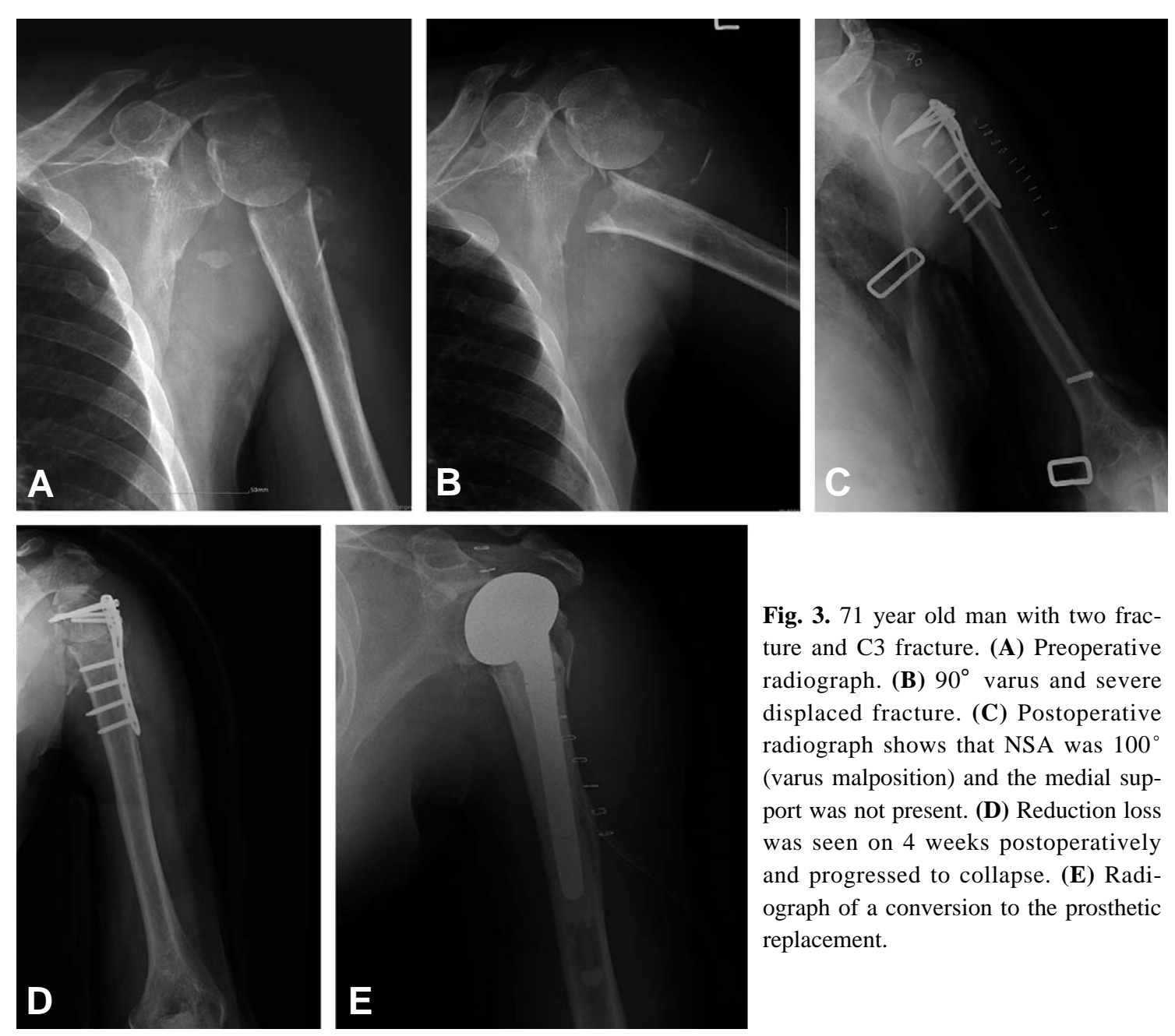

Fig. 3. 71 year old man with two fracture and C3 fracture. (A) Preoperative radiograph. (B) $90^{\circ}$ varus and severe displaced fracture. (C) Postoperative radiograph shows that NSA was $100^{\circ}$ (varus malposition) and the medial support was not present. (D) Reduction loss was seen on 4 weeks postoperatively and progressed to collapse. (E) Radiograph of a conversion to the prosthetic replacement.

고정력은 골절 형태에 따라 금속판의 생역학적 안정화 기전이 다르게 발생하기 때문인 것으로 생각되며, 내반 형 골절에서는 금속판이 내전력에 의해 상완 골두를 잡 아당기는 긴장성 띠 역할을 하게 된다. 따라서 골의 질 이 약한 경우 내전력 (varus force)이 고정력의 약화 를 유발하고, 결국 골의 압축력에 의해 나사의 이완이 발생하게 된다. 이러한 외반 감입 골절과 내반형 골절, 내하방 나사 혹은 골 이식, 즉 내하방 골간단 부위의 보강에 주의한 술기가 상완 골두의 붕괴를 방지하는 가 장 중요한 요소로 생각된다.

Gardner 등 ${ }^{15,16)}$ 은 사체 연구를 통해 액와 신경이 견 봉의 외측 가장자리로부터 평균 $6.3 \pm 0.5 \mathrm{~cm}$ 떨어진 하방을 주행한다고 하였으며, Smith 등 ${ }^{28)}$ 과 Shin 등 ${ }^{29}$ 은 PHILOS 금속판의 근위부 3 열의 나사못 삽입 시 액 와 신경 손상 예방 및 시야 확보를 위해 견관절 외전 자세에서 시행할 것을 권장하였다. 또한 근위판과 나사 를 삽입하는 동안 부드러운 촉진 및 신경의 수지 보호 의 필요성을 강조했다. 그러나 견인 부상을 피하기 위 해 이를 시행하는 것은 권장하지는 않는다. ${ }^{30)}$ 저자들의
경우에는 6 예에서 액와 신경 손상을 의심할 수 있는 소 견이 관찰 되었으며, 전방 굴곡 및 외전 제한을 호소하 였다. 원인으로는 최소 침습 접근법 시 삼각근 절개로 인한 삼각근의 약화나 액와 신경의 금속판에 대한 유 착, 수술 과정에서의 의원성 신경 손상에 의해 발생하 였을 가능성이 있을 것으로 생각하였다.

본 연구의 제한점으로는 삼각 흉간 접근법과 최소 침 습 접근법의 접근법에 따른 임상 결과의 비교가 부족하 였다는 점이며 추후 연구가 필요할 것으로 생각된다.

\section{결 론}

전위된 근위 상완골 골절에 있어 PHILOS 금속판을 이용한 고정술은 술기가 용이하고 만족할 만한 결과를 얻을 수 있는 고정법이라고 생각하였다. 해부학적 정복 에 가장 중요한 두가지 요소는 경간각의 유지와 내측 지지대의 회복이다. 그러나 경간각이 100 도 이하이거나 100 도 이상이더라도 내측 지지대가 존재하지 않고 분쇄 가 심한 경우 수술 후 정복의 소실과 고정물의 실패가 
관찰되어 효과적인 고정 안정성을 기대하기에는 제한이 있으며, 전위된 근위 상완골 골절에서 잠김 압박 금속 판의 유용성에 대한 평가를 위해서는 삼각 흥간 접근법 과 최소 침습 접근법을 비교하는 추가적인 연구가 필요 할 것으로 사료되는 바이다.

\section{REFERENCES}

1. De palma AF. Surgery of the shoulder. 3rd ed, Philadelphia, JB Lippincontt Co. 1983;372-406.

2. Louis UB. Fractures of the proximal humerus. In: Rockwood. C.A. Jr and Masten, F.A. III ed. The shoulder. 1st Ed. Philadelphia, W.B. Saunders Co. 1990; 287-334.

3. Robert HC. Comminuted fractures of the proximal humerus. Clin Orthop Relat Res. 1986;210:49-57.

4. Lill H, Hepp P, Korner J, et al. Proximal humeral fractures: how stiff should an implant be? A comparative mechanical study with new implants in human sepcimens. Arch Orthop Trauma Surg. 2003;123:7481.

5. Bogner R, Hübner C, Matis N, Auffarth A, Lederer $\mathbf{S}$, Resch H. Minimally-invasive treatment of three- and four-part fractures of the proximal humerus in elderly patients. Bone Joint Surg Br. 2008;90:1602-7.

6. Kobayashi M, Watanabe Y, Matsushita T. Early full range of shoulder and elbow motion is possible after minimally invasive plate osteosynthesis for humeral shaft fractures. J Orthop Trauma. 2010;24:212-6.

7. Park CH, Park SH, Seo JS. Internal fixation of proximal humerus fracture with locking compression plate. $J$ Korean Shoulder Elbow Soc. 2009;12:44-52.

8. Ha SS, Kim JY, Hong KD, Sim JC, Kang JH, Park KH. Operative Treatment with Locking Compression Plate (LCP) in Proximal Humerus Fracture. J Korean Shoulder Elbow Soc. 2008;11:137-42.

9. Kristiansen B, Christensen SW. Plate fixation for displaced proximal humeral fractures. Acta Orthop Scand. 1986;57:320-3.

10. Frigg R. Development of the locking compression plate, Injury. 2003;34:6-10.

11. Ha SS, Kim JY, Hong KD, et al. Treatment of Twoand Three-Part Fracture of Proximal Humerus using LCP. J Korean Shoulder Elbow Soc. 2007;10:204-11.

12. Neer CS II. Displaced proximal humeral fractures: classification and evaluation. J Bone Joint Surg Am. 1970;52:1077-89.

13. Constant CR, Murley AH. A clinical method of functional assessment of the shoulder. Clin Orthop Relat Res. 1987;214:160-4.

14. Paavolainen P, Björkenheim JM, Slätis P, Paukku P. Operative treatment of severe proximal humerus fractures. Acta Orthop Scand. 1983;54:374-9.

15. Gardner MJ, Griffith MH, Lorich DG. Helical plat- ing of the proximal humerus. Injury. 2005;36:1197200.

16. Gardner MJ, Weil Y, Baker JU, Kelly BT, Helfet DL, Lorich DG. The importance of medial support in locked plating of proximal humerus fractures. J Orthop Trauma. 2007;21:185-91.

17. Solberg BD, Moon CN, Franco DP, Paiement GD. Surgical Treatment of Three and Four-Part Proximal Humeral Fractures. J Bone Joint Surg Am. 2009;91: 1689-97.

18. Bjorkenheim JM, Pajarinen J, Savolainen V. Internal fixation of proximal humeral fractures with a locking compression plate: a retrospective evaluation of 72 patients followed for a minimum of 1 year. Acta Orthop Scand. 2004;75:741-5.

19. Kettler M, Biberthaler P, Braunstein V, Zeiler C, Kroetz M, Mutschler W. Treatment of proximal humeral fractures with the PHILOS angular stable plate: Presentation of 225 cases of dislocated fractures. Unfallchirurg. 2006;109:1032-40.

20. Agudelo J, Schürmann M, Stahel P, et al. Analysis of efficacy and failure in proximal humerus fractures treated with locking plates. J Orthop Trauma. 2007; 21:676-81.

21. Thanasas C, Kontakis G, Angoules A, Limb D, Giannoudis P. Treatment of proximal humerus fractures with locking plates: a systematic review. J Shoulder Elbow Surg. 2009;18:837-44.

22. Sproul RC, Iyengar JJ, Devcic Z, Feeley BT. A systematic review of locking plate fixation of proximal humerus fractures. Injury. 2011;42:408-13.

23. Röderer G, Erhardt J, Graf M, Kinzl L, Gebhard F. Clinical results for minimally invasive locked plating of proximal humerus fractures. J Orthop Trauma. 2010; 24:400-6.

24. Rouleau DM, Laflamme GY, Berry GK. Proximal humerus fractures treated by percutaneous locking plate internal fixation. Orthop Traumatol Surg Res. 2009;95:56-62.

25. Rancan M, Dietrich M, Lamdark T, Can U, Platz A. Minimal invasive long PHILOS $\left({ }^{\circledR}\right)$-plate osteosynthesis in metadiaphyseal fractures of the proximal humerus. Injury. 2010;41:1277-83.

26. Krappinger D, Bizzotto N, Riedmann S, Kammerlander C, Hengg C, Kralinger FS. Predicting failure after surgical fixation of proximal humerus fractures. Injury. 2011;1:17-22.

27. Resch H, Hübner C, Schwaiger R. Minimally invasive reduction and osteosynthesis of articular fractures of the humeral head. Injury. 2001;32:25-32.

28. Smith J, Berry G, Laflamme Y, Blain-Pare E, Reindl R, Harvey E. Percutaneous insertion of a proximal humeral locking plate: an anatomic study. Injury. 2007;38:206-11.

29. Shin SJ, Do NH, Song MH, Sohn HS. Minimal inva- 
sive plate osteosynthesis in proximal humerus fractures. J Korean Shoulder Elbow Soc. 2010;13:202-8.

30. Saran N, Bergeron SG, Benoit B, Reindl R, Harvey

EJ, Berry GK. Risk of axillary nerve injury during percutaneous proximal humerus locking plate insertion using an external aiming guide. Injury. 2010;41:103740.

\section{초 록}

목적: 전위된 근위 상완골 골절에 대하여 PHILOS 각안정 잠김 압박 금속판을 이용한 수술적 치 료 후 임상적 및 방사선학적 결과와 합병증에 대하여 알아보고자 하였다.

대상 및 방법: 2007년 3월부터 2010년 2월까지 근위 상완골 골절로 PHILOS 금속판 고정술을 시행한 44 명의 환자를 대상으로, 평균 12 개월의 추시 관찰을 시행하였다. 임상적 평가는 VAS 점수와 Constant 점수를 이용하였으며, 방사선학적 평가는 단순 방사선 검사 상 경간각과 내측 지지대의 존재 유무로 평가하였다.

결과: 최종 추시에서 평균 $\mathrm{VAS}$ 점수는 2.8점, Constant 점수는 평균 70.5점이었으며, 방사선 학적 평가 결과 평균 경간각 122.5 도로 양호군은 불량군에 비해 통계적으로 유의한 소견을 보였 다. 내측 지지대가 존재하는 경우 36예 또한 존재하지 않는 8예에 비해 통계적으로 유의하였다. 12 예에서 금속판의 고정 실패 등의 합병증이 관찰되었다.

결론: PHILOS 금속판을 이용한 전위된 근위 상완골 골절 고정술은 술기가 용이하고 만족할 만 한 결과를 얻을 수 있다고 생각된다.

색인 단어: 상완골, 전위 근위 상완골 골절, 각안정 잠김 압박 금속판, PHILOS 금속판 